\title{
Kafatos to be EMBL director; promises greater opportunity
}

Munich. The new head of the European Molecular Biology Laboratory (EMBL) says that he will increase opportunities for women and for scientists from developing countries while increasing cooperative ventures with national research programmes.

Fotis Kafatos, a 53-year-old developmental biologist from Greece, appears to be

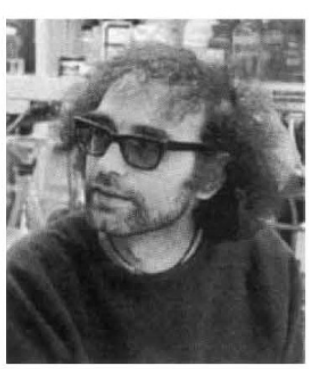

a popular choice as the laboratory's third director-general. $\mathrm{He}$ is the founding director of the 11 year-old Institute of Molecular Biology and Biotechnology in Heraklion, Crete, and is also a full professor at Harvard University.

Fotis Kafatos

Appointed last week by the EMBL Council, Kafatos takes over on a part-time basis next month, assisted temporarily by John Tooze, now executive secretary of the European Molecular Biology Organization. Kafatos becomes full-time in February 1994 , when he also will appoint a director of administration to allow more time for his own scientific work. His laboratory, including some of his team from Heraklion, will continue working on the developmental biology of the mosquito and the fruitfly. "The perspective of an active scientist is very important in directing an institute of this nature", he says.

Kafatos succeeds Lennart Philipson, whose resignation last July exposed deep rifts between the laboratory and its council of 14 member states over the right of a single country to veto EMBL decisions (see $\mathrm{Na}$ ture 358, 267; 1992). The resulting search has been the subject of much unhappy rumour and speculation.

Italy, for example, broke the convention of confidentiality during negotiations by threatening to leave EMBL or to sue the laboratory in international court if Kafatos was allowed to maintain links with his previous institutions. The threats were widely perceived as an attempt to promote the Italian candidate.

But Kafatos has made clear his commitment to the laboratory by resigning his position at Heraklion and by declaring that he will resign from Harvard at the end of his six-month sabbatical. He wants to reestablish a good relationship with member states, calling for a spirit of cooperation between the laboratory and the council to avoid "sabotaging EMBL and the cause of European unification in science".

Kafatos says that his goals can be summarized in three words: excellence, inclusiveness and cooperation. Scientific excellence rather than simple growth is the key to success, he says, in a reversal of a policy of expansion that brought Philipson into conflict with member states hit hard by recession. His commitment to inclusiveness - an acceptance of talent without regard to gender or nationality - should please those who have long felt that women are treated unfairly at EMBL. "Until a couple of decades ago, male scientists were usually oblivious to the talents of even the most remarkable female scientists", he says. Similarly, Kafatos sees

\section{Ruberti modifies fourth Framework}

Munich. The research minister for the European Communities (EC), Antonio Ruberti, has put his own stamp on proposals for European-wide research projects from 1994 to 1998 while endorsing the recommendations of his predecessor, Filippo Pandolfi, for the fourth Framework programme (see Nature 359, 471; 1992).

Ruberti has proposed greater integration with national programmes and with the work of bodies such as the European Molecular Biology Organization, the European Space Agency, the European Science Foundation and the European particle physics laboratory (CERN). He has called for regular meetings of the European research ministers and the heads of national and European research laboratories, a process that the laboratory directors have already begun (see
Nature 361, 576; 1993). He would also like to add projects on transportation and socioeconomic research to the programme.

Ruberti's changes are in line with the recommendations last December of the European Council, which also complained about the cost of Pandolfi's plans. It wants the proposed budget reduced from ECU14.7 billion (US\$20 billion) to between ECU 11 billion and ECU 8 billion. The third Framework Programme cost ECU6.6 billion.

Ruberti admits that the procedures for making decisions are "unwieldy" and that the system must be more flexible. The fourth Framework should also include a programme of technological assessment, he says, to strengthen its industrial base and to match similar programmes in the United States and Japan. scientists from less wealthy European countries, such as his own homeland, as an untapped source of talent.

His wish for closer cooperation between EMBL and member states in scientific ventures has a pragmatic side as well - improved access to outside funds. "If British biology is being rejuvenated by the Wellcome Trust, shouldn't equivalent sources be accessible to the premier international centre of molecular biology in a unifying Europe?" he asks.

Alison Abbott

\section{EMBL selects Cambridge as site for new database}

Munich. The council of the European Molecular Biology Laboratory (EMBL) last week chose Cambridge, England, as the site of a new European Bioinformatics Institute (EBI). EBI will extend the services of EMBL's current data library, primarily a nucleotide and protein sequence database, which has grown too large for EMBL's central laboratory facilities in Heidelberg, Germany.

The decision is a disappointment to the rival bidders, Heidelberg and Uppsala, Sweden (see Nature 361, 383; 1993). EBI planning officer Howard Bilofsky said that the losing bids were "highly credible" but that the "scientific, intellectual and technical environment offered by Cambridge was ideal". Particularly important for the venture are the high-speed data links connecting Cambridge with the rest of the world.

About 70 scientists and technicians will in the next two years move into a customdesigned building on the genome campus at Hinxton Park, nine miles south of Cambridge, already home to the new genome research institute, the Sanger Centre. Some will be drawn from the existing staff of 40 at the data library in Heidelberg, while others will be recruited.

EBI will not raise the cost to member states of participating in EMBL. The US\$12 million needed for the facility will be provided by the British Medical Research Council and the Wellcome Trust. EMBL also plans to hold steady its DM5-million (US\$3 million) contribution to operating the library, which will cost DM12 million annually. EMBL hopes that the European Communities will increase their support to DM5 million and that the remaining DM2 million can be obtained through research grants and contracts with industrial users and others such as the European Patent Office.

EMBL says that services will not be interrupted during the move and that the data library — which each week handles more than a hundred sequence submissions and several thousand requests for data will not be wound down until it is replaced.

Alison Abbott 